\title{
THE DETERMINATION OF SALICYLIC ACID IN WINES USING A LIGAND-EXCHANGE REACTION
}

\author{
Aleksandra Pavlović ${ }^{*}$, Snežana Mitić ${ }^{1}$, Snežana Tošić1, Ružica Micić2 ${ }^{1}$ Ivana Rašić1, \\ Milan Mitić1, Vojkan Miljković ${ }^{3}$ \\ (ORIGINAL SCIENTIFIC PAPER) \\ ${ }^{1}$ University of Niš, Faculty of Sciences and Mathematics, Department of Chemistry, Niš, Serbia \\ 2University of Priština, Faculty of Sciences and Mathematics, Kosovska Mitrovica, Serbia \\ ${ }^{3}$ University of Niš, Faculty of Technology, Leskovac, Serbia
}

The analytical method based on a ligand-exchange reaction is proposed for the determination of salicylic acid (SA) in wines. The reaction was followed spectrophotometrically by monitoring the rate of appearance of the manganese(II)salicylate complex in alkaline medium at $370 \mathrm{~nm}$. The initial-rate method is adopted for constructing the calibration curve, which was found to be linear over the concentration range of $0.69-4.14 \mu \mathrm{g} \mathrm{mL}^{-1}$. The optimized conditions yielded a theoretical detection limit of $0.11 \mu \mathrm{g} \mathrm{mL}^{-1}$ based on the $3-3 S_{0}$ criterion and quantification limit of $0.33 \mu \mathrm{g} \mathrm{mL}^{-1}$ based on the $10 \mathrm{~S}_{0}$ criterion. The results obtained by the proposed method were compared with those obtained by HPLC using UV-DAD detection and showed a good agreement.

Keywords: salicylic acid; kinetic-spectrophotometry; solid-phase extraction; wine; validation

\section{Introduction}

The analysis of wine additives is of considerable commercial importance. Among different additives, antiseptics and antioxidants are commonly used in the wine treatment, and their addition is regulated. Salicylic acid is a powerful antioxidant that helps in lowering cholesterol and prevents blood clots in clogged arteries. In large quantities it is a toxic, but in lower quantities it is used as a food preservative and antiseptic.

For some people with salicylate sensitivity, chronic urticaria patients may react adversely to some food additives [1] and even these small doses can be harmful [2,3]. Because of this, it is important to develop a better understanding of the role of this substance and the adequate levels of intake for good health. Also, developing a sensitive and rapid analytical method for the determination of SA is a key aspect of analytical chemistry.

The large number of batch and automated published methods for the determination of SA is indicative of the great interest in the determination of this compound, but also of the problem encountered with its determination with respect to simplicity, selectivity, sensitivity, rapidity, etc. The development of a simple, rapid to be performed, reliable, selective method for the determination of SA, as an alternative to chromatographic techniques, would be highly advantageous. The analysis of free phenolic acids in wines has been extensively studied by liquid chromatographic methods [4-16]. Diode array detection has been extensively used for the development of liquid chromatography methods $[5,8,9,10,12,14,15]$, whereas fluorimetric $[6,11]$ and mass spectrometry $[4,16]$ detection system has been used to a lesser extent. Most fluorimetric methods proposed have lower detection limits than photometric methods, but these methods have not been widely used in practice because the species that can be detected are limited $[6,11]$. Also, some HPLC methods for SA determination using postcolumn derivatization reaction with teribium(III) [6]. LC-MS is a very expensive technique not widely used in routine laboratories in the wine industry. Spectrophotometry is the technique of choice even today due to its inherent simplicity. It is frequently used in the laboratories of the developing countries to overcome a variety of analytical problems.

\section{Experimental}

\section{Apparatus}

The reaction rate was monitored spectrophotometrically. The absorbance of the solution was measured at the wavelength of $370 \mathrm{~nm}$. The readings were performed on a Perkin-Elmer Lambda 15 UV/Vis spectrophotometer connected to a thermostatic bath $\left(20.00-60.00 \pm 0.02{ }^{\circ} \mathrm{C}\right)$. A model 1200 Agilent Technologies was used for HPLC analysis. A J. T. Baker model SPE-12 with the vacuum pump was used for the solid phase extraction. The solutions were thermostated at $22.00 \pm 0.02{ }^{\circ} \mathrm{C}$ before the beginning of the reaction.

Reagents

Acetonitrile (LC gradient grade) was used from J.T.

\footnotetext{
*Author address: Aleksandra Pavlović, University of Niš, Faculty of Sciences and Mathematics, Department of Chemistry, Višegradska 33, P.O.Box 224, 18000 Niš, Serbia

E-mail: aleksandra.pavlovic@pmf.edu.rs

The manuscript received: March, 24, 2014.

Paper accepted: April, 03, 2014.
} 
Baker and o-phosphoric acid $85 \%$ (analytical reagent grade) was from Merck $\AA$ (KGaA, Darmstadt, Germany) respectively. The $1.0 \times 10^{-3} \mathrm{~mol} \mathrm{~L}^{-1}$ stock solution of salicylic acid (Merck®) was prepared in ethanol (95\%, V/V). The salicylic acid solution was stored at $4^{\circ} \mathrm{C}$. The $1.0 \mathrm{~mol}$ $\mathrm{L}^{-1}$ sodium hydroxide solution (Merck ${ }^{-}$) was prepared in deionised water. The $1.0 \times 10^{-3} \mathrm{~mol} \mathrm{~L}^{-1} 1$-nitroso-2-naphthol solution (Merck $®)$ was prepared by dissolving a known amount in ethanol (95\%, V/V). The manganese(II) solution $\left(1.8 \times 10^{-3} \mathrm{~mol} \mathrm{~L}^{-1}\right)$ was prepared by dissolving $\mathrm{MnCl}_{2} \times 6 \mathrm{H}_{2} \mathrm{O}(\mathrm{Merck} \otimes)$ in water. The ionic strength of the reaction mixture was kept constant at 0.1 by adding the appropriate amount of $\mathrm{NaCl}$ solution $\left(1.0 \mathrm{~mol} \mathrm{~L}^{-1}\right)$. Analytical grade chemicals and deionised water with $0.05 \mu \mathrm{S} \mathrm{cm}^{-1}$ conductivity (MicroMed high purity water system, TKA Wasseraufbereitungssysteme $\mathrm{GmbH}$ ) were used for the preparation of all solutions.

Wines

Six white (vintage 2007) and six red (vintage 2007) commercial wines produced in Serbia (Table 1) in 200 $\mathrm{mL}$ bottles were opened and analyzed within $24 \mathrm{~h}$. In the case that samples required storage, they were kept at 4 ${ }^{\circ} \mathrm{C}$ in a refrigerator.

All analyzed wines were from the West Morava vineyard area. The wines were obtained from the most widespread white grape cultivars (Smederevka, Riesling, Chardonnay and Sauvignon Blanc) and red cultivars (Cabernet Sauvignon, Vranac, Kratošija, Merlot and Game).

Table 1. Wines and grape varieties of the analyzed wines

\begin{tabular}{cl}
\hline Wine $^{\text {a }}$ & Grape varieties \\
\hline W1 & Italian Riesling \\
W2 & Smederevka \\
W3 & Chardonnay \\
W4 & Chardonnay \\
W5 & Chardonnay, Sauvignon Blanc \\
W6 & Italian Riesling \\
W7 & Merlot, Game \\
W8 & Vranac \\
W9 & Kratošija \\
W10 & Game \\
W11 & Cabernet Sauvignon \\
W12 & Vranac \\
\hline${ }^{a}$ W1-W6, white & wines; W7-W12, red wines
\end{tabular}

Kinetic-spectrophotometric procedure

The reaction was carried out in the following way. In a special four-compartment vessel, the solution of 1-nitroso-2-naphthol was placed in the first, salicylic acid and sodium hydroxide in the second, manganese(II) in the third, and electrolyte for the ionic strength and ethanol $(95 \%, \mathrm{~V} / \mathrm{V})$ (total volume $10 \mathrm{~mL}$ ) in the fourth compartment. The vessel was thermostated at $22.00 \pm 0.02^{\circ} \mathrm{C}$. The content was mixed well and then immediately transferred to the spectrophotometric cell. The change in absorbance was recorded at $370 \mathrm{~nm}$ as a function of time every $30 \mathrm{~s}$ for the first $5 \mathrm{~min}$ of the reaction. The rate of the reac- tion at different concentrations of each of the reactants was obtained by measuring the slope of the linear part of the kinetic curves to the absorbance-time. The calibration graph was constructed by plotting the slope of the linear part of the kinetic curve, slope $=d A / d t$, the versus concentration of SA $\left(c_{S A}, \mu \mathrm{g} \mathrm{mL}^{-1}\right)$.

Chromatographic conditions

Salicylic acid was detected and quantified on a 250 x $4.6 \mathrm{~mm}$ Eclipse XDB- $\mathrm{C}_{18}(5 \mu \mathrm{m})$ analytical column operating at room temperature. The mobile phase was a mix of phosphoric acid-acetonitrile-water, 2:400:600 (by vol). The eluate was monitored at $237 \mathrm{~nm}$. The injection of the samples $(10 \mu \mathrm{L})$ was performed by using an autosampler. The flow rate was $1 \mathrm{~mL} \mathrm{~min}^{-1}$.

Analysis of white wine samples

White wine samples were diluted $(1+1)$ with deionized water and directly injected into the chromatographic system. For kinetic application, white wine samples were also directly analyzed following the procedure for the kinetic measurements.

Analysis of red wine samples

When the both methods were applied to the red wine samples, a solid-phase extraction was necessary to remove the coloured compounds and decrease the interference of the matrix. The sample preparation scheme is given in Table 2.

Table 2. Set up parameters for red wine samples preparation

\begin{tabular}{ll}
\hline Parameters & Conditions \\
\hline Adsorbent & Chromabond PS- $\mathrm{OH}^{-}$(Macherey-Nagel) \\
Conditioning & with $2 \mathrm{~mL} \mathrm{CH} \mathrm{CH}_{3} \mathrm{OH}$ than $2 \mathrm{~mL} \mathrm{H} \mathrm{H}_{2}\left(1 \mathrm{~mL} \mathrm{~min}{ }^{-1}\right)$ \\
Sample & $1 \mathrm{~mL}$ \\
Wash & $50 \mathrm{mM} \mathrm{Na}$-acetate in $5 \%$ methanol \\
Drying & under vacum, $2 \mathrm{~min}$ \\
Eluation & $2 \mathrm{~mL} 90: 10 \mathrm{~V} / \mathrm{CH}_{3} \mathrm{OH}: \mathrm{H}_{2} \mathrm{O}$ acidified with glacial $\mathrm{CH}_{3} \mathrm{COOH}$ \\
& $\mathrm{pH} 3-4$ \\
\hline
\end{tabular}

\section{Results and discussion}

\section{Mechanism of the reaction}

SA shows the complexing ability with $\mathrm{Mn}(\mathrm{II})$ [17]. The complex agrees with the empiric formula $\mathrm{Mn}_{2}(\mathrm{HSal})_{4}\left(\mathrm{H}_{2} \mathrm{O}\right)_{4}$. Manganese(II) salicylate complex is more stable than that formed with $\mathrm{R}(\mathrm{NO}) \mathrm{OH}$. The reaction moves to the right (ligand-exchange reaction) and SA was determined by monitoring the rate of appearance of the manganese(II)-1-nitroso-2-naphthol complex at $370 \mathrm{~nm}$.

$2 \mathrm{Mn}[\mathrm{R}(\mathrm{NO})]_{2} \cdot 2 \mathrm{H}_{2} \mathrm{O}+4 \mathrm{SA} \rightarrow\left[\mathrm{Mn}_{2}(\mathrm{HSal})_{4}\left(\mathrm{H}_{2} \mathrm{O}\right)_{4}\right]+$ $4 \mathrm{R}(\mathrm{NO}) \mathrm{OH}$

Optimization of chemical variables

In order to achieve the best sensitivity, the working conditions needed to be optimized.

The effect of the concentration of sodium hydroxide was studied in the range of $0.02-0.10 \mathrm{~mol} \mathrm{~L}^{-1}$. The reaction rate was increased with increasing the concentration of $\mathrm{NaOH}$ up to $0.06 \mathrm{~mol} \mathrm{~L}^{-1}$; beyond this concentration, the rate of the reaction was decreased. For further 
work the concentration of $0.06 \mathrm{~mol} \mathrm{~L}^{-1}$ was used.

The dependence of the reaction rate on the concentration of 1-nitroso-2-naphthol was studied in the range of $0.1-1.0 \times 10^{-5} \mathrm{~mol} \mathrm{~L}^{-1}$. The reaction rate increased with increasing the 1-nitroso-2-naphthol concentration from $0.1-0.6 \times 10^{-5} \mathrm{~mol} \mathrm{~L}^{-1}$ and became constant at $0.6 \times 10^{-5}$ mol L-1. Thus, the concentration of $0.8 \times 10^{-5} \mathrm{~mol} \mathrm{~L}^{-1}$ was chosen as the optimum concentration.

The influence of the concentration of $\mathrm{Mn}$ (II) on the rate of the reaction was examined in the range of $0.5-3.6 \times 10^{-5}$ $\mathrm{mol} \mathrm{L}^{-1}$. The reaction rate increased with increasing the concentration of $\mathrm{Mn}(\mathrm{II})$ from $0.5-1.8 \times 10^{-5} \mathrm{~mol} \mathrm{~L}^{-1}$ and became constant at $1.8 \times 10^{-5} \mathrm{~mol} \mathrm{~L}^{-1}$. Thus the concentration of $2.3 \times 10^{-5} \mathrm{~mol} \mathrm{~L}^{-1}$ in the final solution was used throughout the experiment.

The effect of the temperature on the reaction rate was studied in the range of $18-28{ }^{\circ} \mathrm{C}$. The rate for different concentrations of SA at each temperature was calculated and utilized for plotting the calibration curve. At the temperature $>22^{\circ} \mathrm{C}$, the linear dynamic range of the determination decreased. It was found that the calibration graph obtained at $22^{\circ} \mathrm{C}$ possessed good linearity $(r=0.9989)$ and it is recommended that the determination can be carried out at $22^{\circ} \mathrm{C}$.

Validation of the proposed method

The least squares' equation [18] $(y=b x+a$, where $b$ and a are its slope and intercept, respectively) for the calibration graph and the correlation coefficient $(r)$ for the determination of salicylic acid in the interval 0.69 to $4.14 \mu \mathrm{g} \mathrm{mL}^{-1}$ under the optimal reaction conditions $\left(C_{R(\mathrm{NO}) \mathrm{OH}}=0.8 \times 10^{-5} \mathrm{~mol} \mathrm{~L}^{-1}\right.$, $C_{\mathrm{NaOH}}=0.06 \mathrm{~mol} \mathrm{~L}^{-1}, \mathrm{CMn}^{2+}=2.3 \times 10^{-5} \mathrm{~mol} \mathrm{~L}^{-1}, C_{\mathrm{NaCl}}=0.1 \mathrm{~mol} \mathrm{~L}^{-1}$, $\mathrm{t}=22.00 \pm 0.02^{\circ} \mathrm{C}$ ) were calculated:

slope $\times 10^{2}=0.29649 \times C_{S A}+0.63702 \quad r=0.9997$

where slope is the slope of the linear part of the kinetic curve to the absorbance-time plot (slope $=d A / d t=\varepsilon \cdot \cdot d c / d t$, Beer's law) and $C_{S A}$ is the salicylic acid concentration expressed in $\mu \mathrm{g} \mathrm{mL}^{-1}$.

Quantitative parameters of the analysis are given in Table 3.

Table 3. Quantitative parameters of the analysis

\begin{tabular}{ll}
\hline Parameters & \\
\hline Calibration range $/ \mu \mathrm{g} \mathrm{mL}^{-1}$ & $0.69-4.14, \mathrm{n}=7$ \\
Regression equation & slope $\cdot 10^{2}=0.296 \cdot c_{S A}+0.637$ \\
Slope $\pm \mathrm{SD}$ & $0.296 \pm 0.003$ \\
Intercept $\pm \mathrm{SD}$ & $0.637 \pm 0.007$ \\
Correlation coefficient, $\mathrm{r}$ & $r=0.9997$ \\
Variance $\left(S_{0}^{2}\right) /\left(\mu \mathrm{g} \mathrm{mL}^{-1}\right)^{2}$ & $9.6 \times 10^{-5}$ \\
Detection limit / $\mu \mathrm{g} \mathrm{mL}^{-1}$ & 0.11 \\
Quantification limit $/ \mu \mathrm{g} \mathrm{mL}^{-1}$ & 0.33 \\
\hline
\end{tabular}

The following kinetic equation for the reaction was deduced on the basis of the graphic correlations obtained. rate $=k c_{N a O H} C_{S A}$

$\mathrm{k}$ - constant proportional to the rate constant of the reaction

The limit of the detection was determined as the signal-to-noise ratio $(3.3 \sigma / S)$ and it was $0.11 \mu \mathrm{g} \mathrm{mL}^{-1}$ and the limit of quantification $(10 \sigma / S)$ was $0.33 \mu \mathrm{gL} \mathrm{L}^{-1}$, where $\sigma$ is the standrad deviation of the blank measure (standard deviation of $y$-intercept of regression equation) and is the slope of the calibration curve [19-21].

The precision and accuracy of the above system were studied by performing the experiment five times for different concentrations of salicylic acid. The results of accuracy and precision of the recommended procedure are given in Table 4.

Table 4. The accuracy and precision of the determination of salicylic acid

\begin{tabular}{cccc}
\hline $\begin{array}{c}\text { Taken } \\
\mu \mathrm{mL}^{-1}\end{array}$ & $\begin{array}{c}\text { Found }^{\mathrm{a}} \\
\bar{x} \pm \overline{S D} / \mu \mathrm{g} \mathrm{mL}\end{array}$ & $\begin{array}{c}\mathrm{RS} \\
\%\end{array}$ & $(\bar{x}-\mu) / \mu \cdot 100^{c}$ \\
\hline 0.69 & $0.72 \pm 0.02$ & 4.96 & 4.35 \\
2.07 & $2.03 \pm 0.03$ & 3.08 & -1.93 \\
4.14 & $4.09 \pm 0.02$ & 1.06 & -1.21 \\
\hline
\end{tabular}

${ }^{a}$ Mean and standard deviation of five determinations at $95 \%$ confidence interval, brelative standard deviation, ${ }^{c}$ accuracy of the method

To assess the selectivity of the method, the interference of some species was studied. The tolerance limits (expressed as $w / w$ ratio) for the species studied on the determination of $2.07 \mu \mathrm{g} \mathrm{mL}^{-1}$ of SA are given in Table 5 .

Table 5. The effect of foreign species on the determination of $2.07 \mu \mathrm{g} \mathrm{mL}^{-1}$ salicylic acid

\begin{tabular}{lcc}
\hline Foreign species & $\mathrm{I}^{\mathrm{a}}$ & Tolerance level \\
& $\%$ & $\left(\mu \mathrm{g} \mathrm{mL}^{-1}\right.$ interfering \\
& substance $/ \mu \mathrm{m} \mathrm{ml^{-1 }}$ \\
& $\mathrm{SA})$ \\
\hline
\end{tabular}

$\mathrm{K}^{+}, \mathrm{Li}^{\dagger}$ $5-10$ $10^{3}$

gallic acid, caffeic acid, vanillic acid, 10-15 $10^{2}$ coumaric acid, sinapic acid, catechin, quercetin, ferulic acid, $\mathrm{Cr}^{3+}, \mathrm{Cd}^{2+}, \mathrm{Al}^{3+}$, $\mathrm{Ni}^{2+}, \mathrm{Pb}^{2+}, \mathrm{Co}^{2+}, \mathrm{Se}$

\section{$\mathrm{C}_{2} \mathrm{O}_{4}{ }^{2-}, \mathrm{Ca}^{2+}, \mathrm{Zn}^{2+}, \mathrm{Mg}^{2+}$}

benzoic acid, sorbic acid, $\mathrm{p}$ -

$5-10$

hydroxybenzoic acid, $\mathrm{Ba}^{2+}$

$\mathrm{Fe}^{3+}, \mathrm{Cu}^{2+}$ Interference 1

anterference coefficient, $I=\left(C^{\circ} S A-C S A\right) / C^{\circ} S A$

$\mathrm{C}^{\circ} \mathrm{SA}$ and $\mathrm{C}_{S A}$ are measured concentrations of salicylic acid without and with the interfering substance

Applicability of the method

The proposed method was applied for the determination of salicylic acid in white and red wines using the direct calibration curve. They were treated as described 
in the Experimental section. As it can be seen in Table 6 , the results obtained by this method are in accordance with the HPLC method. The results of the proposed method were statistically compared with those of the official method using a point hypothesis test $[22,23]$. The statistical analysis of the results (Table 6) showed that calculated $\mathrm{F}$ - and $\mathrm{t}$ - values at $95 \%$ confidence levels are less than the theoretical ones, confirming no significant differences between the performance of the proposed and the HPLC method.

Table 6 The determination of salicylic acid in wine samples by the kinetic and HPLC method

\begin{tabular}{|c|c|c|c|c|c|c|}
\hline \multirow[b]{2}{*}{ Samples $^{d}$} & \multicolumn{4}{|c|}{$\begin{array}{l}\text { Found }^{\mathrm{a}} \\
\bar{x}+\overline{S D}\end{array}$} & \multirow[b]{2}{*}{$\begin{array}{c}\text { F- } \\
\text { value }^{c}\end{array}$} & \multirow[b]{2}{*}{$\begin{array}{c}\text { t- } \\
\text { value }^{c}\end{array}$} \\
\hline & Kinetic method & $\begin{array}{c}\mathrm{RSD}^{\mathrm{b}} \\
\%\end{array}$ & HPLC & $\begin{array}{c}\mathrm{RSD}^{\mathrm{b}} \\
\%\end{array}$ & & \\
\hline W1 & $1.39 \pm 0.03$ & 2.01 & $1.35 \pm 0.02$ & 1.70 & 1.48 & 2.211 \\
\hline W2 & $1.01 \pm 0.03$ & 2.84 & $0.98 \pm 0.01$ & 1.33 & 4.97 & 1.889 \\
\hline W3 & $1.15 \pm 0.03$ & 2.35 & $1.12 \pm 0.02$ & 1.61 & 2.25 & 1.853 \\
\hline W4 & $1.03 \pm 0.04$ & 3.79 & $0.99 \pm 0.02$ & 2.22 & 3.14 & 1.807 \\
\hline W5 & $1.43 \pm 0.03$ & 1.89 & $1.40 \pm 0.01$ & 1.0 & 3.72 & 1.976 \\
\hline W6 & $1.06 \pm 0.04$ & 3.77 & $1.08 \pm 0.03$ & 2.59 & 2.04 & 2.001 \\
\hline W7 & $0.57 \pm 0.03$ & 5.91 & $0.54 \pm 0.02$ & 3.15 & 3.93 & 2.071 \\
\hline W8 & $0.38 \pm 0.03$ & 8.34 & $0.35 \pm 0.02$ & 5.43 & 2.78 & 1.624 \\
\hline w9 & $0.42 \pm 0.03$ & 6.90 & $0.38 \pm 0.03$ & 6.74 & 1.24 & 2.053 \\
\hline W10 & $0.59 \pm 0.03$ & 5.03 & $0.55 \pm 0.03$ & 4.78 & 1.28 & 2.259 \\
\hline W11 & $0.63 \pm 0.03$ & 4.14 & $0.65 \pm 0.02$ & 3.82 & 1.11 & 1.245 \\
\hline W12 & $0.40 \pm 0.04$ & 8.87 & $0.43 \pm 0.03$ & 6.21 & 1.73 & 1.521 \\
\hline
\end{tabular}

${ }^{a}$ Data are based on the average obtained from five determinations

${ }^{\mathrm{b}}$ Relative standard deviation

CTheoretical F-value $\left(\mathrm{v}_{1}=4, \mathrm{v}_{2}=4\right)$ and t-value $(\mathrm{v}=8)$ at $95 \%$ confidence level are 6.39 and 2.306 , respectively

\section{Conclusion}

Despite the great number of methods for the analysis of SA described in literature, the proposed kinetic-spectrophotometric method for the determination of salicylic acid in wine samples reported in this paper is simple, rapid, inexpensive, and thus very appropriate for the routine quality control analyses of SA in laboratories in the wine industry. Statistical comparison of the results with the HPLC method showed a good agreement and indicates no significant difference in accuracy and precision. So, the detection limit of $0.11 \mu \mathrm{g} \mathrm{mL}^{-1}$ can be achieved, much better than those provided by fluorimetric [11] or even by HPLC [5] methods. Also, the precision of the proposed method of analysis was found to be good (RSD $<5 \%$ ).

\section{Acknowledgement}

This research was supported by grant number 172047 from the Ministry of Education and Sciences, the Republic of Serbia. The authors are grateful for the financial support provided by this Ministry.

\section{References}

[1] C. E. H. Grattan, Aspirin sensitivity and urticaria, Clinical and Experimental Dermatology, 28(2) (2003) 123-127.
[2] A. Korolkovas, J. H. Burckhalter, Essential of Medicinal Chemistry, John Wiley \& Sons, New York, 1988, p.193.

[3] H. Chi-Tang, Y. L. Chang, H. Mou-Tuan, Phenolic Compounds in Food and their Effects on Health I. Analysis, Occurrence, and Chemistry, American Chemical Society, Washington, 1992, p. 35.

[4] G. L. La Torre, M. Saitta, F.Vilasi, T. Pellicano, G. Dugo, Direct determination of phenolic copmounds in Sicilian wines by liquid chromatograohy with PDA an MS detection, Food Chemistry, 94(4) (2006) 640-650.

[5] M. Calull, R. M. Marce, G. Sanchez, F. Borull, Determination of additives in wine by high-performance liquid chromatography, Journal of Chromatography $A$, 607(2) (1992) 339-347.

[6] M. A. Rodriguez-Delgado, S. Malovana, J. P. Perez, T. Borges, F. J. Garcia-Montelongo, Separation of phenolic compounds by high-performance liquid chromatography with absorbance and fluorimetric detection, Journal of Chromatography A, 912(2) (2001) 249-257.

[7] M. A. Rodriguez-Delgado, G. Gonzalez-Hernandez, J. E. Conde-Gonzalet, J. P. Perez-Trujillo, Principal component analysis of the polyphenol content in young red wines, Food Chemistry, 78(4) (2002) 523-532.

[8] P. Ho, T. A. Hogg, M. C. M. Silva, Application of a liquid chromatographic method for the determination of phenolic compounds and furans in fortified wines, Food Chemistry, 64(1) (1999) 115-122.

[9] Q. Zhang, H. Cui, A. Myint, M. Lian, L. Liu, Sensitive determination of phenolic compounds using highperformance liquid chromatography with cerium(IV)rhodamine 6G-phenolic compund chemiluminiscence 
detection, Journal of Chromatography A, 1095(1-2) (2005) 94-101.

[10] R. Sladkovsky, P. Solich, M. Urbanek, High-performance liquid chromatography determination of phenolic components in wine using off-line isotachophoretic pretreatment, Journal of Chromatography A, 1040(2) (2004) 179-184.

[11] R. C. Rodriguez-Diaz, M. P. Aguilar-Caballos, A. GomezHens, Determination of some hydroxybenzoic acids and catechins in white wine samples by liquid chromatography with luminescence detection, Journal of Separation Science, 29(18) (2006) 2772-2779.

[12] R. J. Robins, S. R. Bean, Development of a quantitative high-performance liquid chromatography-photodiode array detection measurement system for phenolic acids, Journal of Chromatography, 1038(1-2) (2004) 97-105.

[13] R. C. Minussi, M. Rossi, L. Bologna, L. Cordi, D. Rotilio, G.M. Pastore, N. Duran, Phenolic compounds and total antioxidant potential of commercial wines, Food Chemistry, 82(3) (2003), 409-416.

[14] V. F. Samanidou, C. V. Antoniou, I. N. Papadoyannis, Gradient RP-HPLC determination of free phenolic acids in wines and wine vinegar samples after SPE, with photodoide array identification, Journal of Liquid Chromatography and Related Technology, 24(14) (2001) 2161-2176.

[15] Z. Kerem, B. Bravdo, O. Shoseyov, Y. Tugendhaft, Rapid liquid-chromatography-ultraviolet determination of organic acids and phenolic compounds in red wines and must, Journal of Chromatography A, 1052(1-2) (2004) 211-215.
[16] M. N. Bravo, S. Silva, A. V. Coelho, L. Vilas-Boas, M. R. Bronze, Analysis of phenolic compounds in Muscatel wines produced in Portugal, Analytica Chimica Acta, 563(1-2) (2006) 84-92.

[17] R. A. Lal, A. Lemtur, S. Choudhury, M. Chakrabarty, D. Basumatary, M. K. Singh, S. Bhaumik, A. K. De, A. Kumar, Synthesis and crystal structure of [Mn2(H2Sal)2(HSal)2(H2O)4]. First example of the reductive synthesis of a binuclear manganese(I) salicylate complex, Transition Metal Chemistry, 31(4) (2006) 423428.

[18] J. N. Miller, Basic Statistical Methods for Analytical Chemistry. Part 2. Calibration and Regression Methods, Analyst, 116 (1991) 3-14.

[19] D. Perez-Bendito, M. Silva, Kinetic Methods in Analytical Chemistry, Ellis Horwood, Chichester, 1988, p. 251.

[20] H. A. Mottola, Kinetic Aspects of Analytical Chemistry, John Wiley \& Sons, New York, 1988, p. 40.

[21] V. Thomsen, D. Schatzlein, D. Mercuro, Limits of Detection in Spectroscopy, Spectroscopy, 18(12) (2003) 112-114.

[22] C. Hartmann, J. Smeyers-Verbeke, W. Penninckx, Y. V. Heyden, P. Vankeerberghein, D. L. Massart, Reappraisal of Hypothesis Testing for Method Validation: Detection of Systematic Error by Comparing the Means of Two Methods or of Two Laboratories, Analytical Chemistry, 67(24) (1995) 4491- 4499

[23] D. A. Skoog, D. M. West, F. J. Holler, Fundamentals of Analytical Chemistry, Saunders College Publishing, Philadelphia, 1996, p. 42.

\section{Izvod \\ ODREĐIVANJE SALICILNE KISELINE U VINU NA OSNOVU REAKCIJE IZMENE LIGANADA}

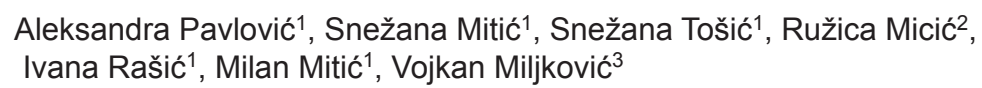

\footnotetext{
1 Univerzitet u Nišu, Prirodno-matematički fakultet, Departman za hemiju, Niš, Srbija

2Univerzitet u Prištini, Prirodno-matematički fakultet, Kosovska Mitrovica, Srbija

${ }^{3}$ Univerzitet u Nišu, Tehnološki fakultet, Leskovac, Srbija
}

U radu je predložena metoda za određivanje salicilne kiseline (SA) u vinu koja se zasniva na reakciji izmene liganada. Reakcija je praćena spektrofotometrijski, merenjem brzine obrazovanja kompleksa između mangana i salicilne kiseline u baznoj sredini na $370 \mathrm{~nm}$. Korišćenjem metode početnih brzina kostruisana je kalibraciona prava, koja je linearna u opsegu koncentracija 0,69-4,14 $\mu \mathrm{g} \mathrm{mL}^{-1}$. Optimizovanjem uslova metode, dobijene su vrednosti za granicu detekcije ( $10 S_{0}$ kriterijum) i granicu određivanja ( $3,3 S_{0}$ kriterijum) od $0,11 \mu \mathrm{g} \mathrm{mL}-1$ i $0,33 \mu \mathrm{g} \mathrm{mL}^{-1}$, respektivno. Razvijena metoda je primenjena za određivanje salicilne kiseline u uzorcima vina. Dobijeni rezultati su poređeni sa rezultatima dobijenim HPLC hromatografijom, pri čemu je pokazano da postoji dobro slaganje između dva niza rezultata.
(ORIGINALNI NAUČNI RAD) UDC 547.587.11+663.2:543.48

Ključne reči: salicilna kiselina, kinetičkaspektrofotometrija, ekstrakcija u čvrstoj fazi, vino, validacija 